\title{
PENGEMBANGAN BAHAN AJAR DIGITAL SEJARAH LOKAL BERBASIS TOPONIMI DI VORSTELANDEN SURAKARTA
}

\author{
Leo Agung S., Muh Akhyar \\ Email : leo.agung56@yahoo.co.id
}

\begin{abstract}
Abstrak
Pembelajaran sekarang ini tidak bisa lepas dari pemanfaatan teknologi, termasuk pembelajaran sejarah di SMA. Hal ini dapat dilihat dari penggunaan internet sebagai sumber referensi belajar peserta didik, khususnya di sekolah menengah dan perguruan tinggi. Bahan ajar yang digunakan tidak harus bahan ajar cetak, tapi dapat non cetak artinya wujud dari produk bahan ajar digital yang dihasilkan berupa modul digital dalam bentuk software. Dalam proses penggunaannya guru atau siswa harus menginstal modul digital pada komputer, laptop dan smartphone berbasis android. Pengembangan bahan ajar dalam bentuk modul digital ini selaras dengan perkembangan dan inovasi dalam bidang pendidikan dan sesuai dengan era digital sekarang. Bahan ajar digital yang dikembangkan terkait dengan sejarah lokal berbasis Toponimi di Vorstelanden Surakarta.
\end{abstract}

Kata kunci : Bahan Ajar digital, Toponimi, Vorstenlanden, dan Sejarah Lokal

\section{Pendahuluan}

Pembelajaran sekarang ini tidak bias lepas dari pemanfaatan teknologi Hal ini dapat dilihat dari penggunaan internet sebagai sumber referensi belajar peserta didik, khususnya di sekolah menengah dan perguruan tinggi. Bedasarkan survei yang dilakukan oleh e-Marketer, sebuah Lembaga riset pasar mengtakan bahwa netter di Indonesia pada tahun 2014 mencapai 83,7 juta orang yang diproyeksikan akan mencapai 112 juta pada tahun 2017, pertumbuhan netter Indonesia diperkirakan akan mengalahkan Jepang yang menggalami tingkat pertumbuhan netter yang lebih lamban. Hal ini dikarenakan Indonesia merupakan negara berkembang yang tentunya akan memiliki peluang lebih besar dalam peningkatan infrastruktur yang memadai (Yusuf,2014).

Pemanfaatan teknologi mendukung arus informasi global mudah diakses lewat internet. Kondisi ini bertolak belakang dengan minimnya akses informasi tentang sejarah lokal. Padahal peristiwa sejarah lokal di lingkungan peserta didik memiliki peran mengaktualisasikan unsur pembelajaran dan pendidikan. Usur pertama adalah pembelajaran (instruction) dan pendidikan intelektual (intellectualtraining) dam usur kedua adalah pembelajaran dan pendidikan moral bangsa dan civil society yang demokratis dan bertanggung jawab kepada masa depan bangsa. 
Pembelajaran sejarah merupakan sebuah wacana intelektual yang kritis dan rasional, yang dicapai melalui tiga tahapan (Abdullah \& Aini, 2007) yakin (1) memupuk kesadaran atas lingkungan social, rasa keakraban (sense of intimacy); (2) memperkenalkan siswa pada makna dari dimensi waktu dalam dinamika kehidupan (sense of actuality) dan (3) rasa hayat sejarah (sense of history).

Kedekatan emosional siswa dengan lingkungan sekitar merupakan sumber belajar sejarah yang berharga bagi terjadinya proses pembelajaran di kelas. Sebagaimana diungkapkan Beck dalam Nana Supriatna (2008), setiap individu atau kelompok masyarakat memiliki keunggulan dan local genius, ataau center of a scholarship, dan menjadi pusat keunggulan atau central tradition of scholarship. Salah satu pembelajaran sejarah yang ada lingkungan sosial peserta didik adalah Toponimi Vorstenlanden Surakarta.

Toponimi adalah asal - usul nama tempat. Setiap nama tempat, kampung ataupun desa mempunyai sejarahnya sendiri - sendiri yang unik dan menarik karena mempunyai karakteristik masyarakat berdasarkan latar belakang historisnya (Sugeng Priyadi, 2012). Toponimi sarat nilai - nilai edukatif dan kultural. Penelitian Karen Hikkila (dalam Umar dan Sariyatun, 2017) terhadap nama lokal di Kanada menunjukkan perspektif dari nama - nama yang menggunakan Bahasa lokal sebagai sarana mengkomunikasikan pengetahuan tentang alam, Bahasa asli dan sejarah lisan. Penelitian ini juga menunjukkan nilai toponimi adat setempat dalam pendidikan, terutama dalam konsep pengajaran navigasi, pengajaran ekologi, menjelajahi perputaran musim, dan membangun kesadaran lingkungan. Derek H. Alderman \& Joshua Inwood (dalam Umar, 2017) menyatakan bahwa nilai yang terkandung dalam toponimi, salah satu yang terpenting adalah memberikan "clues" ataupun petunjuk bagi warisan sejarah dan budaya suatu tempat dan wilayah.

Toponimi di Vorstenlanden Surakarta akan menjadi bahan pembelajaran sejarah lokal yang menarik apabila dikemas menjadi buku digital atau dikenal dengan e-book. Buku digital atau electronic book adalah buku dalam bentuk digital, yang terdiri dari teks, gambar, atau keduanya. Dengan demikian perlu dikembangkan buku digital sejarah lokal berbasis toponimi Vorstenlanden Surakarta, sebagai upaya mewujudkan pembelajaran sejarah pendidikan intelektual (intellectual training), serta pendidikan moral bangsa dan civil society. Pemanfaatan buku digital sejarah lokal berbasis toponimi akan menumbuhkan empati sejarah (historical empathy) siswa. Empati sejarah (historical empathy) memiliki dimesi kognitif (memahami) dan 
afektif (merasakan, peka, peduli) yang sangat diperlukan bagi generasi muda untuk ikut bertanggung jawab menjaga tempat tinggalnya yang mengandung nilai - nilai sejarah. Dengan demikian model dikembangkan merupakan bagian dari revitalisasi peninggalan bersejarah.

\section{Pembelajaran Sejarah di SMA}

Sejarah merupakan salah satu mata pelajaran wajib di sekolah menengah. Sebagai salah satu pelajaran wajib, pembelajran sejarah merupakan bagian yang tidak terpisahkan dari kurikulum yang berlaku dan juga Pendidikan Nasional secara umum. Dengan begitu, maka pembelajaran sejarah yang dilangsungkan pada dasarnya juga merupakan bagian yang tidak terpisahkan dai upaya pencapaian tujuan Pendidikan nasional. Hanya saja, karena setiap mata pelajaran mempunyai karakteristik yang berbeda, maka tentu juga akan terdapat perbedaan orientasi dalam pencapaian tujuan tersebut. Adapun untuk mata pelajran sejarah di SMA, pembelajaran yang dilaksanakan tidak terlepas dari Pendidikan sejarah secara umum, yakni sebagai suatu proses internalisasi nilai - nilai, pengetahuan dan keterampilan kesejarahan dari serangkaian peristiwa yang dirancang dan disusun sedemikian rupa untuk mempengaruhi dan mendukung terjadinya proses belajar peserta didik, (Depdikbud.2013:2).

Lebih lanjut dijelaskan bahwa untuk pembelajaran sejarah di SMA, pembelajarn dirancang untuk membekali peserta didik supaya memiliki beberapa hal sebagai berikut : a) mengembangkan pengetahuan dan pemahaman mengenai perjalanan kehidupan masyarakat dan bangsa Indonesia serta dunia; b) mengembangkan rasa kebangsaan, cinta tanah air, dan penghargaan terhadap hasil dan prestasi bangsa di masa lalu; c) membangun kesadaran tentang konsep waktu dan ruang dalam berpikir kesejarahan; d) mengembangkan kemampuan berpikir sejarah (historical thinking), keterampilan sejarah (historical skills), dan wawasan terhadap isu sejarah (historical issues), serta menerapkan kemampuan, keterampilan dan wawasan tersebut dalam kehidupan masa kini; e) mengembangkan perilaku yang didasarkan pada nilai dan moral yang mencerminkan karakter diri, masyarakat dan bangsa; f) menanamkan sikap berorientasi kepada masa kini dan masa depan; g) memahami dan mampu menangani isu -isu kontroversial untuk mengkaji permasalahan yang terjadi di lingkungan masyarakatnya; h) mengembangkan pemahaman internasional dalam menelaah fenomena aktual dan global (Depdikbud.2013:2).

Senada dengan beberapa rumusan di atas, Said Hamid Hasan (2012:49) menjelaskan bahwa Pendidikan Sejarah di SMA memiliki tujuh, yakni : a) mengembangkan pendalaman 
tentang peristiwa sejarah yang terpilih baik lokal maupun nasional; b) mengembangkan kemampuan berpikir kritis dan kreatif ; c) membangun kepedulian dan semangat kebangsaan; d) mengembangkan rasa ingin tahu, inspirasi, dan aspirasi; e) mengembangkan sikap kepahlawanan dan kepemimpinan; f) mengembangkan kemampuan mencari, megolah, mengemas informasi; dan g) mengkomunikasikan. Pendapat yang hampir sama juga dikemukan oleh Garvey dan Krug dalam bukunya Models of History Teaching in The Secondary School. Menurutnya, ada lima tujuan dari pembelajaran sejarah yakni: a) memperoleh pengetahuan tentang fakta - fakta sejarah ; b) mendapatkan pemahaman atau penghargaan mengenai peristiwa, periode atau masyarakat yang hidup di masa lampau; c) memperoleh kemampuan dalam menilai dan mengkritik tulisan sejarah: d) memperlajari bagaimana melakukan penelitian sejarah; dan e) mempelajari cara menuliskan sejarah (Garvey \& Krug.2015:2).

Lebih lanjut Kochar (2008:27) membagi tujuan umum pembelajaran sejarah sebagai berikut : a) Mengembangkan pemahaman tentang diri sendiri, b) Memberikan gambaran yang tepat tentang konsep waktu, ruang, dan masyarakat, c) Membuat masyarakat mampu mengevaluasi nilai - nilai dan hasil yang telah dicapai oleh generasinya, d) Mengajarkan toleransi, e) Menanmkan sikap intelektual, f) Memperluas cakrawala intelektuliatas, g) Mengajarkan prinsip - prinsip moral, h) Menanamkan orientasi ke masa depan, i) Memberikan pelatihan mental, j) Melatih siswa menangani isu - isu kontroversial, k) Membantu mencarikan jalan keluar bagi berbagai masalah sosial dan perseorangan, 1) memperkokoh rasa nasionalisme, m) mengembangkan pemahaman internasional, dan n) Mengembangkan keterampilan keterampilan yang berguna.

Berdasarkan beberapa rumusan di atas, dapat disimpulkan bahwa secara garis besar, terdapat tiga kategori tujuan atau kompetensi yang ingin dicapai melalui pembelajaran sejarah di SMA. Pertama, kompetensi kognitif, yakni berupa pengetahuan kesejarahan, Kedua, kompetensi prsikomotorik, yakni berupa keterampilan sejarah. Ketiga, kompetensi afektif atau sikap yang berupa nilai - nilai kesjarahan.

Berdasarkan uraian di atas, maka dapat pula ditarik kesimpulan bahwa pembelajran sejarah bukanlah hanya sekedar usaha membekali peserta didik dengan pengetahuan kesejarahan semata. Lebih penting daripada itu, ialah berupa internalisasi nilai - nilai kesejarahan, baik yang bersumber dari peristiwa sejarah, teladan dari tokoh atau pelaku sejarah, kebudayaan, ataupun yang lainnya yang kemudian dapat berbuah pada pembentukan watak dan karakter peserta didik 
sebagai generasi penerus bangas. Sebagaimana diungkapkan oleh Supardan (2014:189) bahwa pembelajaran sejarah merupakan sebuah proses untuk membantu mengembangkan potensi serta kepribadian peserta didik melalui pesan - pesan sejarah agar menjadi warga bangsa yang arif dan bermartabat. Karena itu, aspek sikap atau nilai - nilai merupakan aspek penting yang harus diperhatikan dalam proses pembelajaran sejarah di sekolah, termasuk di SMA.

Sebagaimana diungkapkan oleh Abbas (1998:82) bahwa Pendidikan sejarah perlu mentransfer nilai - nilai etika dan moral yang mendasari cara berfikir, cara bersikap, cara berperilaku seseorang untuk mewujudkan keharmonisan kehidupan individu, kelompok, masyarakat atau bangsa dalam membangun perdamaian, toleransi, dan kesediaan menerima perbedaan. Karena itu, pembelajaran sejarah yang dilangsungkan bukanlah hanya sekedar mempelajari peristiwa masa lampau semata, melainkan mengambil hikmah atau pelajaran dari peristiwa tersebut untuk dijadikan sebagai pedoman dalam bertindak di kehidupan masa kini, (Abdulgani.1980:4; Soedjatmoko.1992:56; Kartodirdjo.1993:33).

\section{Pengembangan Bahan Ajar Digital}

Bahan ajar adalah segala bentuk bahan yang digunan untuk membantu guru atau instuktur dalam melaksanakan kegiatan belajar mengajar di kelas (Depdiknas.2017:3). Dick \& Carey (2009:242) mengatakan bahwa bahan ajar merupakan seperangkat materi atau substansi pembelajaran (teaching material) yang disusun secara sistematis, menampilkan sosok utuh dari kompetensi yang akan dikuasai oleh peserta didik dalam kegiatan pembelajaran. Dari sudut pandang perkembangan ilmu pengetahuan dan teknologi pendidikan, bahan ajar adalah segala bentuk bahan yang digunakan untuk membantu guru atau instruktur dalam melaksanakan kegiatan belajar mengajar di kelas (Depdiknas.2017:3).

Tujuan penyusunan bahan ajar berdasarkan Depdiknas (2017:10) antara lain : (1) menyediakan bahan ajar yang sesuai dengan tuntutan kurikulum dengan mempertimbangkan kebutuhan siswa, sekolah, dan daerah; (2) membantu siswandalam memperoleh alternatif bahan ajar; dan (3) memudahkan guru dalam melaksanakan pembelajaran. Sedangkan penulisan bahan ajar memiliki lima (5) manfaat penting sebagai berikut : (1) membantu guru dalam proses pembelajaran; (2) memudahkan penyajian materi di kelas; (3) membimbing siswa belajar dalam waktu yang lebih banyak; (4) siswa tidak tergantung kepada guru sebagai satu - satunya sumber 
informai; (5) dapat menumbuhkan motivasi siswa untuk mengembangkan diri dalam mencerna dam memahami pelajaran.

Tujuan penyusunan bahan ajar berdasarkan Depdiknas (2017:10) antara lain : (1) menyediakan bahan ajar yang sesuai dengan tuntutan kurikulum dengan mempertimbangkan kebutuhan siswa, sekolah, dan daerah; (2) membantu siswandalam memperoleh alternatif bahan ajar; dan (3) memudahkan guru dalam melaksanakan pembelajaran. Sedangkan penulisan bahan ajar memiliki lima (5) manfaat penting sebagai berikut : (1) membantu guru dalam proses pembelajaran; (2) memudahkan penyajian materi di kelas; (3) membimbing siswa belajar dalam waktu yang lebih banyak; (4) siswa tidak tergantung kepada guru sebagai satu - satunya sumber informai; (5) dapat menumbuhkan motivasi siswa untuk mengembangkan diri dalam mencerna dam memahami pelajaran.

Proses penyusunan bahan ajar menurut Prastowo (2011: 49) terdiri atas tiga tahapan yaitu sebagai berikut:

1) Melakukan analisis kebutuhan, langkah-langkahnya meliputi menganalisis:

a. Kurikulum (KI, KD, indikator, materi pokok, pengalaman belajar);

b. Sumber belajar (ketersediaan, kesesuaian, kemudahan);

2) Memilih dan menentukan bahan ajar.

3) Memahami kriteria pemilihan sumber belajar.

a. Kriteria umum (ekonomis, praktis, mudah didapat, dan fleksibel);

b. Kriteria khusus (memotivasi peserta didik dalam belajar, mendukung KBM, penelitian, memecahkan masalah, dan presentasi).

Lebih detail Prastowo (2013) menegaskan langkah-langkah pengembangan bahan ajar digital dapat dijabarkan secara rinci sebagai berikut: (1) judul diturunkan dari kompetensi dasar atau materi pokok sesuai dengan besar kecilnya materi; (2) petunjuk pembelajaran dituliskan secara jelas, supaya peserta didik mudah dalam menggunakannya; (3) informasi pendukung dijelaskan secara jelas, padat, dan menarik dalam bentuk tertulis atau gambar diam maupun bergerak; (4) tugas-tugas ditulis dalam program interaktif; (5) penilaian dapat dilakukan terhadap hasil karya dari tugas yang diberikan pada akhir pembelajaran, yang dapat dilihat oleh pendidik melalui komputer; serta (6) gunakan berbagai macam sumber belajar yang dapat memperkaya materi. 
Pengembangan bahan ajar digital pada penelitian ini berlandaskan pada bahan ajar jenis non cetak, artinya wujud dari produk bahan ajar digital yang dihasilkan berupa modul digital dalam bentuk software. Dalam proses penggunaannya dosen atau mahasiswa harus menginstal modul digital pada komputer, laptop dan smartphone berbasis android. Pengembangan bahan ajar dalam bentuk modul digital ini selaras dengan perkembangan dan inovasi dalam bidang pendidikan dan sesuai dengan era digital sekarang.

\section{Toponimi Bagian dari Sejarah Lokal}

Istilah toponimi di Jndonesia masih asing di telinga. Secara sederhana, toponimi yaitu pengetahuan yang mengkaji riwayat atau asal-usul nama tempat (Jacub Rais [et.al]., 2008:54; Rachmat Ruchiat, 2012:xiii). Toponimi dapat digolongkan sebagai salah satu cabang dari onomastika, yaitu pengetahuan mengenai nama. Cabang lainnya dari onomastika ialah "antoponim," yaitu pengetahuan yang mengkaji riwayat atau asal-usul nama orang atau yang diorangkan (Jacub Rais [et.al]., 2008:53-54) dengan berbagai atributnya, antara lain gelar, pangkat, kedudukan dan tentu saja silsilahnya (Rachmat Ruchiat, 2012:xiii). Selain mempelajari masalah nama, ilmu ini juga mengkaji pembakuan penulisan, ejaan, pengucapan (fonetik), sejarah penamaan, serta korelasi nama dengan kondisi alam atau sumberdaya yang dimiliki sebuah unsur geografi.

Di lain pihak, toponimi memiliki segitiga (triangel) konsep yang dikemukakan oleh Susanto Zuhdi (2013), yaitu "bahasa sebagai pencerah" (language as enlightenment); "sejarah sebagai pengingat" (histopy as remembrance) dan "tradisi sebagai kesinambungan" (tradition as continuity). Dalam segitiga konsep tersebut tampak bahwa aspek linguistik, sejarah, dan budaya/kultural menjadi bagian tidak terpisahkan dari toponimi. Toponim dapat dilihat sebagai ekspresi linguistik yang mempertautkan gagasan manusia dengan obyek, seperti pada gunung, sungai, laut, selat, pulau dan sebagainya. Lisa Radding \& John Western (2010:407) mengidentifikasikan toponimi sebagai 'tanda' ("signs") yang menghubungkan pengalaman hidup manusia yang pernah tinggal di suatu tempat.

Toponimi juga dapat ditelusuri dari aspek semiotika atau studi tentang tanda-tanda, lambang atau simbol. Rais Jacub, et.al. (2008: 458) mengungkapkan pendekatan semiotika dapat mengekplorasi makna ataupun pesan dari komunikasi budaya yang disebarkan lewat sejumlah nama-nama tempat. Aspek simbolis yang penting dari budaya adalah bahasa, penggunaan kata- 
kata untuk mewakili benda dan pandangan. Simbol yang diartikan lewat bahasa adalah penting bagi suatu budaya sehingga antropolog Kluckohn menuliskan "budaya manusia tanpa bahasa tidak dapat dipikirkan." Lewat bahasa, manusia dapat u dari pengalaman yang terakumulasikan dan dibagikan (Larry A. Samovar, Richard E Porter \& Edwin R. McDaniel, 2010:45-46)

Dalam pandangan Vygotsky, bahasa merupakan alat kultural paling penting yang menghubungkan kognisi siswa dengan objek-objek kulturalnya. Toponimi memberikan kesempatan bagi dunia pendidikan dalam pemeliharaan bahasa dan pembelajaran tradisi lisan, kedua isu penting yang mendasari kelangsungan budaya suatu tempat. Mengetahui nama-nama tempat dan cerita dari tanah air seseorang adalah bagian dari mengetahui bahasa dan warisan seseorang (Karen Heikkilä, 2010:117).

Selain memperlihatkan aspek bahasa, toponim juga tidak lepas dari sejarah, yang berfungsi sebagai "pengingat." Fokus sejarah adalah pada fakta dan interpretasi. Melalui fakta sejarah manusia ınampu mengingat mengenai peristiwa, baik sebagai proses maupun sırukturnya. Berdasar pada fakta itü manusia memberi makna bagi kehidupannya. Nama tempat (toponimi), peristiwa, waktu dan tokoh adalah elemen penting yang tersaji dalam suatu penelitian sejarah. Menurut Louis Gottschalk (2006:92), sebuah nama memberikan informasi sejarah.

Vorstenlanden merupakan suatu istilah yang dipakai pada sejarah Jawa untuk menyebut daerah-daerah yang berada di bawah otoritas empat monarchi asli Jawa pecahan Dinasti Mataram Islam; yakni Kasunanan Surakarta, Kasultanan Yogyakarta, Kadipaten Mangkunegaran, dan Kadipaten Pakualaman. Awalnya Vorstenlanden membentang di sepanjnag sisi selatan mulai dari sekitar Gunung Slamet di Jawa tengah sampai sekitar Gunung Kelud di Jawa Timur. Kondisi demikian berlangung selama 75 tahun, yakni sekitar tahun 1755 sampai dengan 1830. Sejak tahun 1830, sebagai dampak kebijakan pemerintah kolonial Belanda pasca Perang Jawa/Diponegoro (1825-1830), luas wilayah Vorstenlanden menciut secara drastis. Sejak tehun tersebut, Vorstenlanden tinggal meliputi daerah-daerah eks Karesidenan Surakarta dan Provinsi Daerah Istimewa Yogyakarta.

Menurut Wasino (2014) pada tahun 1847 ketika di bawah Mangkunegara III, Kadipaten Mangkunegaran di bagi menjadi tiga daerah Onderregent (Kadipaten Anom) yaitu Karanganyar ( meliputi Sukowati, Matesih dan Haribaya), Wonogiri ( meliputi Nglaroh, Hanggabayan dan Kedawung, dan Malang Jiwa (Kartasura pasa masa lampu). 
Sekitar tahun 1946 Kapanewon atau Kecamatan Kota Mangkunegaran berganti nama menjadi Kecamatan Banjarsari yang terdiri dari 13 kelurahan dengan toponiminya, di antaranya adalah:

1. Kelurahan Timuran, diambil dari nama Kanjeng Pangeran Haryo Mangkudiningratan atau Pangeran Timur. Beliau bertempat tinggal di depan Mangkunegara sebelah barat. Dalam perkembangannya rumah beliau menjadi rumah putri Van Deventer (sekarang SMP Negeri 3 dan SMP Negeri 10 Surakarta).

2. Kelurahan Punggawan, pada awalnya merupakan tempat peristirahatan para abdi dalem atau punggawa Mangkunegaran yang rumahnya jauh, yang datang saat Mangkunegarakan mengadakan acara

3. Kelurahan Kestalan, diambil dari bahasa Belanda "Stall, yang berarti kandang uda. Awalnya wilayah ini digunakan sebagai kandang kuda atau gedhongan. Selain itu juga sebagai tempat merawat kuda yang sakit, dan tempat mengubur kuda yang mati.

4. Kelurahan Stabelan, yang namanya diambil dari nama "Setabel" atau prajurit meriam. Awalnya wilayah ini merupakaj tempat tinggal prajurit meriam. Di antara Kelurahan Stabelan dan Kelurahan Kestalan terdapat alun-alun yang luas yang disebut alun-alun balapan, karena sering digunakan untuk balapan kuda. Selain itu, alun-alun ini digunakan untuk latihan barus berbaris serta berkuda Prajurit Legium Mangkenegaran.

5. Kelurahan Manahan, awalanya daerah ini tempat latihan dan kegiatan memanah.

6. Kelurahan Mangkubumen, diambil dari nama seorang Pangeran yang bertempat tinggal di daerah ini yakni Kanjeng Gusti Pangeran Haryo Mangkubumi.

7. Kelurahan Gilingan, awalnya merupakan tempat penggilingan padi. Kampung ini terletak di sebelah utara stasiun Balapan.

8. Kelurahan Keprabon, merupakan tempat tinggal dari menantu Pakubuwana III yang bernama Kanjeng Pangeran Arya Prabuwijaya. Kampung ini terletak di depan istana Mangkunegaran.

9. Kelurahan Nusukan, berasal dari kata nusuk, berati sudet atau tembus. Sudetan Kali Pepe ini dibuat agar banjir tidak memasuki kota yang dibangun pada tahun 1908 atas kerjasama Mangkunegaran dan Kasunanan.

Itulah beberapa contoh toponimi yang ada di Vorstenlanden Surakarta khusunya di Mangkunegaran.

620 | Seminar Nasional Sejarah ke 4 Jurusan Pendidikan Sejarah Universitas Negeri Padang 


\section{Simpulan}

Bahan ajar menjadi sarana bagi guru dan siswa untuk memahami materi pembelajaran.

Sesuai dengan tututan Kurikulum, bahwa pembelajaran sejarah harus menyentuh aspek pengetahuan, aspek sikap dan aspek keterampilan, maka pembelajaran sejarah harus dikemas sedemikian rupa sehingga menjadi pembelajaran yang menarik dan menantang. Dengan demikian, pengembangan bahan ajar digital sejarah lokal berbasis toponimi di Vorstelanden Surakarta sangat diharapkan guna peningkatan kuliats pembelajaran khususnya pembelajaran sejarah.

\section{DAFTAR PUSTAKA}

Abdulgani, Roeslan. (1980). Penggunaan Ilmu Sejarah. Bandung : Prapantja.

Abdullah \& Aini, Hassan.(2007). Empati Sejarah dalam Pengajaran dan

Sejarah. (Versi Elektronik). Jurnal Pendidik dan Pendidikan, Jilid 22; 61-74

Abdullah, Taufik.(2005). Sejarah Lokal di Indonesia. Yogyakarta : Gajah Mada University Press.

Borg, R. Walter dan Gall, Meredith D. (2007). Educational research: An introduction. Eihgth Edition. Sydnet : Pearson Education, Inc.

Bucher, Slavomir.et.al.(2013). The Perseption on Identity Through Urban Toponym in the Region Cities of Slivakia. (Versi Eletronik). Antropological Notebook, 19 (3): $23-40$.

Depdiknas, (2017). Pengembangan Bahan Ajar . Jakarta : Depdiknas

Dick, Walter ; Carey, Lou \& Carey, James O. (2009). The systematic design instructional. New Jersey : Pearson Education Upper Saddle River.

Heikkilä, Karen . (2010).Indigenous Toponyms as Pedagogical Tools: Reflection from Research Study. (Versi elektronik). Fennia 188:1, 105-122

Gottschalk, Louis. (2006). Mengerti Sejarah. Terjemahan Nugroho Notosusanto. Jakarta.Universitas Indoensia Press.

Kartodirdjo, Sartono. (1982). Pemikiran dan Perkembangan Historiografi Indonesia, Suatu Arternatif. Jakarta : Gramedia 
Kochhar, S.K. (2008). Pembelajaran Sejarah. Terjemahan Purwanta dan Yovita Hardiwati. Jakarta : Grasindo

Prastowo.(2013). Pengembangan Bahan Ajar. Jakarta : Rajawali Press

Priyadi, Sugeng. (2012). Sejarah Lokal, Konsep, Metode dan Tantangan. Yogyakarta : Ombak

Radding, Lisa \& Western, John.(2010). What's In A Name? Linguistics, Toponyms Geography and , Toponyms. (Versi Eletronik). The Geographical Review 100

(3): July 2010, 394-412

Rais, Jacub., (et.al). (2008). Toponimi Indonesia Budaya yang Panjang dari Pemukiman Manusia dan Tertib Administrasi. Jakarta : Pradnya Paramita

Schunk, Dale H. (2012). Teori-Teori Perkembangan:Perspektif Pendidikan, Edisi Keeenam. Yogyakarta : Pustaka Pelajar.

Soedjatmoko. (1992). Dimensi Manusia Dalam Pembangunan. Jakarta : LP3ES

Sugiyono. (2010). Metode penelitian pendidikan: pendekatan kuantitatif, kualitatif, dan $R$ \& $D$. Cetakan ke-10. Bandung: Penerbit Alfabeta.

Supriyatna Nana. (2008). Pembelajaran Sejarah Berorientasi Pada Masalah-Masalah Kontemporer. Disertasi tidak diterbitkan. Bandung : Program Pascasarjana. Universitas Pendidikan Indonesia.

Vasina, Jan. (2014). Tradisi sebagai Sejarah. Yogyakarta : Ombak

Zuhdi, Susanto (2013). Sejarah sebagai Pengingat dan Pemakna. Slide PPT . makalah Seminar Nasional Toponimi: Peran Toponimi Dalam Pelestarian Budaya Nasional. Bandung. 